\title{
自己愛傾向が自己像の不安定性, 自尊感情のレベルおよび変動性に及ぼす影響
}

\author{
小塩 真 司 ${ }^{1)}$ \\ 名古屋大学大学院教育発達科学研究科
}

本研究では, 自己愛傾向と自己像の不安定性, 日常の自尊感情レベルおよび変動性との関連, ならび に自己愛傾向が自己像の不㚣定性を媒介して自尊感情の高さおよび変動性に与える影響について検討し

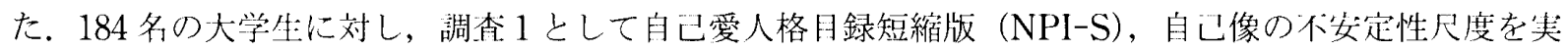
施し, 調查 2 として 1 日の出来事, その出来事の評価, 自尊感情尺度を 6 日間連続で記入する日記法に 上る調査を奏施した。絬果から，自己愛傾向のうち「優越感・有能感「自己主㖘性」が日常の自尊感情 の高さに関連し，「注月・賞賛欲求」が自己像の不安定性および自尊感情の変動性に関連することが示さ れた。 またパス解析の結果から，「優越感・有能感」「自己主張性」が自尊感情のレベルに正の影響を与 えること,「注目・賞賛欲求」が自己像の不安定性を媒介して自尊感情の変動性に正の影響を与寺, 自尊 感情のレベルに負の影響を与えることが示された。

キーワード：自己愛傾向，自尊感情レベル，自尊感情の㚣定性，自己像の不安定性

\section{問 題}

\section{自己愛と自尊感情}

自己愛の最も基本的な意味は自分が自分を愛す ること（小此木，1981）であり，自尊感情（自尊 心 : self-esteem) は自己概念と結びついている自 己の価值と能力の感覚（遠藤，1992）と定義され る。このように自己愛と自尊感情は，自分自身に 対する肯定的感覚といら点で類似した概念である. 調査的な先行研究でも, 自己愛傾向全体は自尊感 情と正の相関関倸にあることが示されている

(Emmons, 1984; Gabriel, Critelli \& Ee, 1994; Jackson, Ervin \& Hodge, 1992; 小塩，1997，1998; Raskin, Novacek \& Hogan, 1991; Rhodewalt, Madrian \& Cheney, 1998; Rhodewalt \& Morf, 1995; Watson \& Biderman, 1993).

一方で先行研究の中には, 自己愛がいくつかの

1)現所属は中部大学人文学部.
下位側面から構成され，その中には自尊感情に関 連する側面としない側面が存在することを指摘す るものもある. 例えば理論的な先行研究では, Pulver （1970）は「健康な (良い：good)自己愛」と「不健 康な(悪い：bad)自己愛」を分けて捉え，前者は防 衛的でない本質的な自尊感情に関連し，後者は好 ましくない自己評価に対して自分自身を防衛する という，防衛的プライドに関連すると述べている。 また調査的な先行研究でも，自己愛傾向の全ての 下位尺度が自尊感情と正の相関関係を示すわけで はないことが明らかにされている，例えば海外で は「他者の利用・権利の主張 (exploitativeness / entitlement)」下位尺度が自尊感情と無相関である ことが報告されている (Emmons, 1984; Jackson et al., 1992; Rhodewalt \& Morf, 1995).またわ が国では，「他者の利用・権利の主張」下位尺度と 多くの共通する項目をもつ「注目・賞賛欲求」下 位尺度が，自尊感情と無相関であることが報告さ れている（小塩，1997，1998）。このように, 自尊 
感情との関連を検討する際には，自己愛の下位側 面に焦点を当てる必要があると考えられる。

自己愛と白尊感情に注概念上の相違もある。例 えば，自己愛が人格障害として扱われるように否 定的な意味あいも含むパーソナリティ概念である のに対し，自尊感情は心理的な適忍の指標として 用いられるなど，両者はやや異なる意味あいをも つ. また自尊感情は自己の感情的評価に関連し, 日常の肯定的・否定的ライフイベントに影響を受 けるように（例えば高比良，1998），一時的な自己 評価も念屯概念である（Westen，1990）。その一 方で自己愛は，一時的な自己評価といらよりも比 較的長期間にわたって見られる安定した人格であ り，これまでの理論的変遷の中で，一種の性的倒 錯, 心理社会的発達の一段階, 特異な対象関係, 自尊感情を調整する働きなど様々な意味を有して きた概念である（Pulver，1970）。近年では， Sedikides（1993）が自己愛の中心的特徵忙自己高 撕にあると述べているよらに，自尊感情を調整す る働きとしての自己愛が注目されている。本研究 では，日常の様々な出来事を経験する中で変化す る，一時的な自己に対する感情的評価としての自 尊感情に注目する。そしてそのような日常の自尊 感情に影響を与えるパーソナリティ要因の1つと して，自己愛傾向に注目する.

\section{自己愛と自尊感情の安定性}

臨床事例に基づく理論的な先行研究では，自己 愛の高い者の自尊感情が不安定であるという指摘 がなされている。例えば DSM-IV（American Psychiatric Association, 1994）における自己愛 人格障害の記述では，自己愛人格障害をもつ者の 自尊感情が非常にもろい（fragile）ことが指摘さ れている，また Westen（1990）は，自己愛的な者 は極度の過大評価と全体的な自暴自棄の間を交互 に繰り返すと述べている。これらの指摘は，自己 愛の高い者の自尊感情のあり方を考慮する場合に， 自尊感情の全体的な高さだけではなく，日常的な 自尊感情の変動にも注目する必要があることを示
していると考えられる。

近年，そのような自尊感情の姿定性（stability） に注目する調査的研究がいくつか行われている(Kernis, Brown \& Brody, 2000; Kernis, Cornell, Sun, Berry \& Harlow, 1993; Kernis, Grannemann \& Barclay, 1992; Kernis, Whisenhunt, Waschull, Greenier, Berry, Herlocker \& Anderson, 1998; Waschull \& Kernis, 1996)。自尊感情の安定性は 短期的な自尊感情レベルの変動の大きさを意味し， 2 度にわたる自尊感情尺度の実施に㧍ける回答の一 致度（Kugle, Clements \& Powell, 1983）や, 47 日間毎日 1 度加 2 度評定される自尊感情尺度の 個人内の標淮偏差（Kernis et al., 1993 など）に よって測定される. Kernis, Brown \& Brody (2000) は，不安定な自尊感情は自己価值の傷つきやすい 感情を反映すると述べている。

そして Rhodewalt et al.（1998）は先に示した Westen (1990) の主笘に注目し, 被験者に対し56 日間連続してその日の感情と自尊感情を記入卞 るように求め，自己愛傾向と日常の感情および自 尊感情との関連を検討している。そして自己愛傾 向が日常の感情および自尊感情の変動の大きさに 関連することを示している。

ただし自己愛傾向と自尊感情の変動性との関連 を検討する際にも，自己愛傾向の下位側面を考慮 寸る必要があると考えられる。例えば DSM-IV (American Psychiatric Association, 1994)では, 自尊感情のもろさ潦大な賞賛を要求する自己愛 人格の特徴とされている。 また調査的な先行研究 に打いても，自己愛傾向の中のある下位尺度が自 尊感情の変動性に関連することを示唆する研究が ある。例えば Emmons（1987）汢日常的な感情を 42 日間連続で報告させ，自己愛傾向との関連を検 討する中で, 自己愛傾向の下位側面の5ち特に「他 者の利用・権利の主張」下位尺度が感情の変動に 関連することを報告している。おが国では小塩 （1998）が，自己愛傾向の下位尺度のらち「注目・ 賞賛欲求」について，自分では自信をもっている 
が，同時にその自信は他者からの評価によって容 易に崩れてしまうようなあり方を意味すると考察 している。海外に打沙る「他者の利用・権利の主 張」下位尺度とわが国における「注目・賞賛欲求」 下位尺度の項目内容の共通性を考慮すると, 自己 愛傾向の下位側面のうち「注目・賞賛欲求」が不 安定な自尊感情に関連することが示唆される。と ころが Rhodewalt et al.（1998）をはじめこれま での調査的な先行研究では, 自己愛傾向の下位側 面と自尊感情の変動性との関連を検討した研究は 見あたらない。

\section{自己愛と自己像の不安定性}

本研究では，自己像の不安定性（Rosenberg， 1965）にも注日したい. Westen（1990）は，自己 愛人格の自己像が著しく歪んで㧍り, 安定してい ないことを指摘している。また伊藤（1989）も， Kohut（1971）とKernberg（1975）に共通する自 己愛人格障害の臨床的特徴の 1 つとして, 自己に ついての不確実感を挙げている。このように理論 的な先行研究では, 自己愛と自己像の不安定性と の関連が示唆されている。

加えて, 自己像が不安定であることは自尊感情 の基盤が不安定であることも意味するため,

Rosenberg（1965）が示唆するように自尊感情レ ベルの低下に結びつくと考えられる．また Kernis et al.（1998）は，不安定な自尊感情に影響を与え る要因の 1 つして貧困な自己概念 (impoverished self-concept）を挙げている. 自己像が不安定な者 は，自己を評価する際の基準が曖昧であり，日常 の様々な出来事を経験する中で自尊感情が変動し や寸くなるとも考えられる。しかしこれまでに自 己愛傾向, 自己像の不安定性, 自尊感情のレベル や変動性との関連を検討した研究は見あたらない。

\section{本研究の目的}

本研究では, 日常の様々な出来事に影響を経験 する中で変化する，一時的な自尊感情に注目し， その上うな自尊感情に影響を与える要因として自 己愛傾向と自己像の不安定性を取り上げる。そし
て先に取り上げた先行研究から, 第 1 に自己愛傾 向の中には日常的な自尊感情のレベルに影響を与 える側面があること，第 2 に自己愛傾向の中には 自尊感情の日常的な变動性に関連する側面がある こと，第 3 に自己愛傾向の自尊感情の高さや変動 性への影響は直接的なものとは限らず，自己愛傾 向が自己像の不安定性を導き, その自己像の不安 定性が自尊感情の高さや変動性に影響を与える可 能性のあることが考えられる。

Wolf, Gedo \& Terman（1972） は青年期老, 児童期に確立された自我理想が疑われ，新たな理 想が構築される時期としている.そしてAdelson \& Doehrman（1980）によると，この時期の変化は 自己愛の高まりを導き，自己や人格の統合性が妿 かされるといら。ささにこの時期は傷つきやすさ や，頻繁な自尊感情の変動が顕著であると述べて いる。このように, 自己愛, 自尊感情の高さや変 動性, 自己像の安定性といら概念の相互関連を検 討することは，青年期発達においても重要な意味 をもつと考えられる。

以上の上うな問題意識に基づき, 本研究では第 1 に，自己愛傾向，自尊感情の高さおよびその変動 性, 自己像の不安定性についてその相互関連を検 討する。そして第 2 に，自己愛傾向が自己像の不 安定性を媒介して自尊感情の高さおよび変動性に 与えるというモデルについて検討することを目的 とする.

\section{方 法}

\section{調査内容}

以下に示す $2 つ の$ 調査を行った。

\section{調査 1 （a）自己愛人格目録短縮版 (NPI-S; Nar-} cissistic Personality Inventory-Short version) 小塩（1999）によって作成された NPI-S を用いた. NPI-Sは「優越感・有能感「注目・賞賛欲求」「自 己主張性」の 3 つの下位尺度, 30 項目（各下位尺 度 10 項目ずつ）からなる。「全く当てはまらない」 から「とてもよく当てはまる」までの 5 件法で測 
定した.（b）自己像の不安定性 Rosenberg（1965） が作成した Stability of Self Scale 考参考に, 5 項目からなる自己像の不安定性尺度を新たに作成 した。「全く当てはまらない」から「とてもよく当 てはまる」までの 5 件法で測定した，得点が高い ほよ゙，自己像が不安定であることを意味する。

調査 26 日間毎晚記人する B 6 判の大きさの小 冊子を用意した。冊子はフェイスシートと6枚の 記人用紙からなっており，各記入用紙には日付と 曜日が印刷してある。記入する内容は以下の通り である．1．記入時刻．2．出来事：その日に起き た最も印象的な出来事の自由記述. 3. 出来事の評 価：その出来事がどの程度良い（悪い）出来事で あったかを「悪い（1点）「どちらかというと悪 い（2 点)」「どちらともいえない（3 点）」「どち らかというと良い（4点）「良い（5点）」の5件 法で測定した４．自尊感情：日常の自尊感情を測 定するために，Rosenberg（1965）の自尊感情尺 度の日本語版（桜井，1997）を使用した。この尺 度はパーソナリティ特性としての自尊感情を測定 するために用いられることが多いが，日常の肯定 的・否定的ライフイベントに影響を受けることも 知られている（高比良，1998）。もしもこの尺度が 時間を超えて変動しない真の特性を測定するもの であり，一時的な測定値の变動が測定誤差にすぎ ないのであれば，肯定的・否定的ライフイベント のような関連変数との間には関連が見られないと 考えられる。しかし，実際に関連変数との共変関 係が確認されている以上，この尺度で一時的な自 己評価も測定できるといら可能性梳否定できない であるう。加えて，海外に执ける多くの先行研究 (Kernis et al., 1992; Kernis et al., 1993; Rhodewalt et al., 1998）では，日常の自尊感情を測定するた めに Rosenberg（1965）の尺度を用いている。そ こで本研究においても同様に Rosenberg（1965） の尺度を用いた１0項目からなり，「全く当てはま らないっからとてもよく当てはまる」までの 5 件 法で測定した。

\section{手続き}

調査 1 は 2000 年 11 月に, 講義時間を利用して 一斉に行执た。 そして調查 1 の終了後, 調查 2 を 行らために被調查者に小冊子を配布し，次の日の 夜から6 日間, 毎晚就寝前に記入するように求め た。調查 1 は月曜日に行い, 翌週の月曜日に調查 2 の冊子を回収した。被調査者の照合には学籍番号 を用いた。な抢，この調査を行った週に祝日はな かった。

\section{調査対象・分析対象}

調査 1 亿参加した者は愛知県内の大学生 195 名

（男性 85 名，女性 110 名）であった。そして翌週 に調査 2 の冊子を持参し，回答に不備のあるもの を除いた 184 名（男性 81 名，女性 103 名; 平均年 歯令 20.29 歳, $S D=1.03,19-28$ 歳）分析の対象 とした。

\section{結 果}

\section{調査 1 のデータの整理}

NPI-S NPI-Sの30 項目について，3因子に対 志寸る仮説的因子パターン $(1$ または 0$)$ をター ゲットとして，反復主因子法・斜交 Procrustes 回 転による確認的因子分析を行った。その結果, Procrustes 回転後の因子パターンは仮説的因子パ ターンとほぼ一致していた. Procrustes 回転後の 因子パターンと仮説的因子パターンの当該因子間 の一致係数を算出したところ「優越感・有能感」 で.92,「注目・賞賛欲求」で.95, 「自己主張性」 で.89 と十分な值が得られたため, オリジナルの尺 度構成のまま分析を進めることにした，得点化に ついては，NPI-Sの3つの下位尺度に相当する項 目の得点を合計し，それぞれ「優越感・有能感」 得点 $(M=27.68, S D=5.28, \alpha=.81)$ 「注目・賞 賛欲求」得点 $(M=33.11, S D=6.72, \alpha=.87)$, 「自 己主張性」得点 $(M=31.55, S D=5.59, \alpha=.77)$ を算出した.

自己像の不安定性 自己像の不安定性尺度 5 項 目について, 逆転項目の処理を行った後に主成分 
Table 1 自己像の不安定性の主成分分析結果

\begin{tabular}{|c|c|}
\hline \multicolumn{2}{|l|}{ 項目内容 } \\
\hline 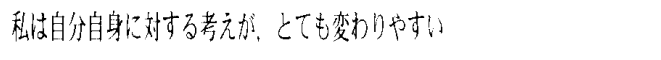 & .87 \\
\hline 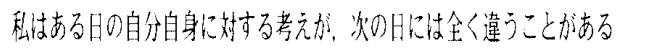 & .88 \\
\hline 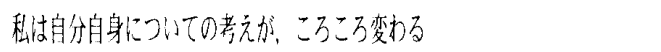 & .81 \\
\hline 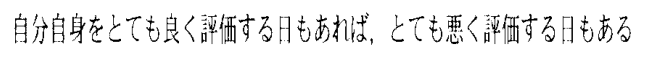 & .82 \\
\hline 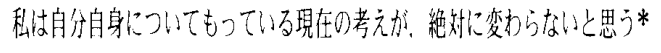 & .50 \\
\hline 寄与 & 3.11 \\
\hline 寄与率 (\%) & $62.16 \%$ \\
\hline
\end{tabular}

分析を行った。第 1 因子の固有値が 3.11 と十分に 高いのに対し，第 2 因子以降の固有值は 1 未満で あったことから，明確な 1 因子性が認められ，全 ての項目が第 1 主成分に $.50-.88$ の負荷量を示し た (Table 1). 1 因子による説明率は $62.16 \%$ であっ た. 5 項目の得点を合計することで自己像の不安定 性得点 $(M=17.68, S D=4.07, \alpha=.84)$ を算出した.

これらの 4 つ得点について男女差の検討を行っ たところ，いずれの得点についても有意な男女の 得点差は見られなかった。

\section{調査 2 のデータの整理}

出来事の評価 出来事の記述は様々であり，例 えば“恋人とのデート”や“コンサートに行く” などが良い出来事，“授業への遅刻”や“友人との けんか”などが悪い出来事と評価されていた。 日々 の出来事の評価は様々であるが, 本研究で沬 6 日 間を通じた全体的な出来事の評価に注目する。そ こで 6 日間の出来事の評価の平均值を算出し, 日 常の出来事の評価得点とした $(M=3.29, S D=.69)$. これは得点が高いほど出来事を肯定的に評価する ことを表す。火曜日から日曜日まで 6 日間の出来 事の評価得点の平均および $S D$ を Table 2 に示す.

自尊感情のレベル 各曜日について, 逆転項目 の処理を行った後に全 10 項目の得点を合計し, 各 曜日の自尊感情得点を算出した。平均および $S D を$ Table 2 に示す. 各曜日間の相関係数を算出したと ころ, $r=.59$ (水曜と木曜) から $r=.71$ （土曜と 日曜) と,相互に正の相関関倸にあった(全て $p<.001)$.
Table 26 日間の出来事の評価および自尊感情得点

\begin{tabular}{|c|c|c|c|c|}
\hline & \multicolumn{2}{|c|}{ 出来事の評価 } & \multicolumn{2}{|c|}{ 自尊感情 } \\
\hline & 平均 & $(S D)$ & 平均 & $(S D)$ \\
\hline 火曜目 & 3.31 & (1.57) & 32.58 & $(7.02)$ \\
\hline 水曜月 & 3.22 & $(1.53)$ & 32.66 & (6.69) \\
\hline 木嚁等 & 3.32 & $(1.45)$ & 32.31 & $(7.11)$ \\
\hline 金曜日 & 3.17 & $(1.45)$ & 31.80 & $(6.77)$ \\
\hline 1:曜川 & 3.29 & $(1.49)$ & 33.02 & $(6.94)$ \\
\hline 11曜川 & 3.40 & $(1.46)$ & 33.21 & $(6.86)$ \\
\hline 平均 & 3.29 & $(.69)$ & 32.60 & $(5.82)$ \\
\hline
\end{tabular}

各個人の 6 日間の自尊感情得点の平均值を算出す ることにより,日常の自尊感情レベルとした $(M=$ $32.60, S D=5.82)$. ここで用いた全 60 項目の $\alpha$ 倸 数は.97であった。なお, 各曜日における出来事 の評価得点と自尊感情得点との相関係数は $r=.23$ （水曜日 $; p<.01 ）$ 加 $r=.33$ （土曜日 $; p<.001 ）$ の間にあり, 異なる曜日に扮ける出来事の評価得 点と自尊感情得点との間には有意な相関が見られ なかった（ $r=-.12$ から $r=.07)$.

自尊感情の変動性 先行研究 (Kernis et al., 1993 など）に従い，個人内における6日間の自尊感情 得点の標淮偏差を算出し, 日常の自尊感情の変動 性得点とした $(M=3.14, S D=2.00$ ；最小值 0.00 , 最大値 12.76).

なおこれらの 3 つの得点について男女差の検討 を行ったところ, 日常の自尊感情レベルについて 女性よりも男性の方が有意に得点が高かった（男 性 $M=33.54, S D=6.08$; 女性 $M=31.85, S D=5.53$; $t(182)=1.97, p<.05)$.

\section{各得点間の相関}

各得点間の相関を Table 3 に示す。自己像の不 安定性と「注目・賞賛欲求」との間に低い值であ るが有意な正の相関が見られた，日常の自尊感情 レベルは「優越感・有能感」自己主張性」と有意 な正の相関関係にあるが，「注目・賞賛欲求」とは 無相関であり，自己像の不安定性とは低い值であ るが有意な負の相関関係にあった，日常の自尊感 情の変動性と「注目・賞賛欲求」および自己像の 
Table 3 各得点間の相関

\begin{tabular}{|c|c|c|c|c|c|c|c|}
\hline & 1 & 2 & 3 & 4 & 5 & 6 & 7 \\
\hline 1. 優越感 · 有能感 & - & & & & & & \\
\hline 2. 注目・賞替欲求 & $.29^{* * *}$ & - & & & & & \\
\hline 3. 自己主張性 & $.39^{* * *}$ & $.16^{*}$ & - & & & & \\
\hline 1. 自己像の不安定性 & .05 & $.27^{* * *}$ & .00 & - & & & \\
\hline 5. 出来事の秤価 ${ }^{1)}$ & -.05 & .04 & .05 & .02 & - & & \\
\hline 6. H常の自尊感情レベル & $.43^{* * *}$ & .05 & $.37^{* * *}$ & $-.17^{*}$ & $.16^{*}$ & - & \\
\hline 7. 归常の自尊感情変動性: & .01 & $.16^{*}$ & .11 & $.25^{* * *}$ & -.07 & -.11 & - \\
\hline
\end{tabular}

$* p<.05, * * p<.01, \quad * * * p<.001$

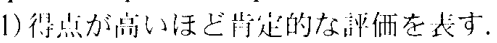

不安定性との間に有意な正の相関関係が見られた。 出来事の評価については日常の自尊感情レベルと の間に低い值であるが有意な正の相関関係が見ら れたのみであった。

\section{パス解析}

モデルの設定 Table 3 の結果から，自己愛傾向 の3つの下位側面のらち「優越感・有能感」と「自 己主張性」が日常の自尊感情レベルに影響を与え ると考えられる。この 2 つの下位尺度は自己に対 寸る誇大な感覚やその感覚に基づく自己中心的な 態度を意味しており，そのような自己愛の持ち主 は日常的に高い自尊感情を保つことができると考 えられる，その一方で Table 3 より，自己愛傾向 の 1 側面である「注目・賞賛欲求」は，日常の自 尊感情の変動性に結びつくと考えられる。ただし，

「注目・賞賛欲求」が直接的に日常の自尊感情の 変動性に結びつくのか, 自己像の不安定性を媒介 して日常の自尊感情の変動性に結びつくのかは, Table 3 の結果のみでは分からない，そこで，「注 目・賞賛欲求」と自己像の不安定性がそれぞれ直 接的に日常の自尊感情の変動性に結びつくモデル A と, 「注目・賞賛欲求」が自己像の不安定性を媒 介して日常の自尊感情の変動性に結びつくモデル B 在設定した。これらをパス図に示したものが Figure 1である（ただし Figure 1 には後述する分 析結果も併記してある)。な扮出来事の評価につい ては, Table 3 において自己愛傾向の各得点や自己
像の不安定性との関連が見られなかったことから， これらの得点からの影響を受计ず，自尊感情に影 響を与える外生変数として扱った。

モデルの比較 UNIX版 SAS (6.12) のCALIS プロシジャを用い，モデル A とモデル Bについて， 構造方程式を用いた観測変数の分析を行った。 Figure 1 には，各モデルの GFI（適合度指標）, AGFI（修正適合度指標)，AIC (Akaike's Information Criterion) も示されている. モデル A で は $\mathrm{GFI}=.99, \mathrm{AGFI}=.95$, モデル $\mathrm{B}$ では $\mathrm{GFI}=.99$, $\mathrm{AGFI}=.96$ といずれも十分高い值を示しており, 構成されたモデルは標本共分散行列をよく説明し ていることが示された。 そこで，両モデルの適合 性の比較を行うために AIC の值を見たところ，モ デル A ではー3.76, モデル Bではー9.44 とモデル Bの方が小さいといら結果であった。従って，モデ ル $\mathrm{B} の$ 方がモデル $\mathrm{A}$ に比べモデルとしての妥当性 が高いことが示された。さらに，モデル Aの「注 目・賞賛欲求」から日常の自尊感情の変動性への パス係数は.10であり, 統計的に有意でない $(t=$ $1.36, n . s$.$) ことから，この間の因果関係が見られ$ ないことが示された。

以上の結果から，「注目・賞賛欲求」と自己像の 不安定性がそれぞれ直接的に日常の自尊感情の変 動性に結びつくといら仮説（モデルA）よりも，「注 目・賞賛欲求」が自己像の不安定性を媒介して日 常の自尊感情の変動性に結びっくという仮説（モ 


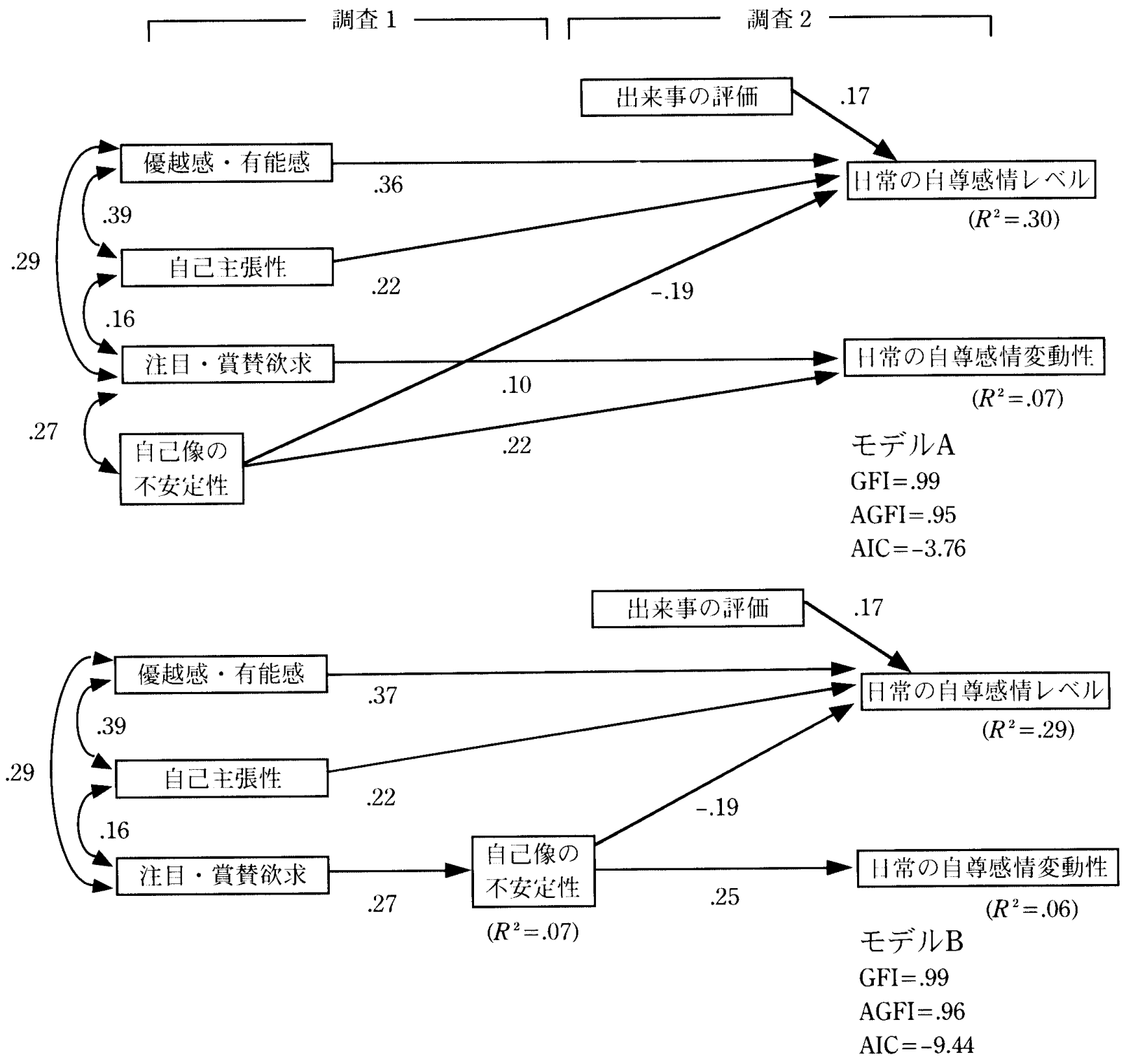

Figure 1 パス図

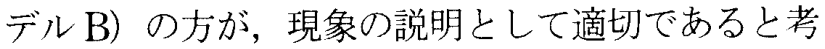
它らる.

\section{考 察}

NPI-S で測定される自己愛傾向のらち，「優越感・ 有能感」は他者よりも優れて抢り有能であるといつ た強い自己肯定感を意味し，「自己主非性」は自分 の意見を述べるなど，能動的で積極的な自己愛傾 向の側面（小塩，1998）を意味する。 Table 3 より， これら2つの下位側面は日常の自尊感情レベルと 正の相関関係にあり，Figure 1 より，「優越感・有
能感」「自己主張性」が日常の自尊感情レベルを高 める要因となることが明らかにされた。この結果 はこれまでの先行研究（小塩，1997，1998）加 も予想される結果である。

本研究で得られた自尊感情レベルと「優越感・ 有能感」自己主張性」との間の相関係数を見ると, 「優越感・有能感」で $r=.43$, 「自己主張性」で $r$ =.37である．一方で小塩（1997）は，自尊感情と 「優越感・有能感」との間に $r=.50$,「自己主張性」 との間に $r=.38$ という相関係数を報告して抢り， これは本研究で得られた值と同程度であるといえ 
る. 本研究では先行研究（小塩, 1997）と㳉異な る自尊感情尺度を用いており，また自尊感情を集 団調査ではなく日常生活の中で測定している。従っ て, 自尊感情レベルと「優越感・有能感」「自己主 張性」との間に打ける中程度の正の相関関係は, 異なる自尊感情尺度を用いた場合でも，また測定 状況を変えた場合でも見られる，比較的安定した 関係にあるといえるだろう。

また，自己愛傾向の下位側面のらち「注目・賞 賛欲求」は他者に注目され賞賛されたいといった， 他者からの肯定的評価を強く期待する内容で構成 されている. Figure 1 では, 自己像の不安定性を 媒介して日常の自尊感情レベルを抑制する要因と なることが示された。従って「注目・賞賛欲求」 の高い者は, 自尊感情の基盤となる自己像が不安 定であるため, 日常の様々な経験をする中で自尊 感情の維持が難しく，自尊感情が低下しやすくな ると考えられる。このように，自己愛傾向の下位 側面の中には日常の自尊感情レベルを高める要因 となるものと, 抑制する要因となるものが存在す るといえよう。

本研究では自尊感情のレベルだけではなく，日 常的な自尊感情の変動性にも注目した。各曜日間 の自尊感情得点は相互に高い正の相関関係にあり, 被調査者が前日の回答を覚えているなどの，学習 効果の影響が示唆される。しかし，連続する 2 日 間の相関係数が連続しない曜日間の相関係数より も高くなるという結果は得られておらず，相互相 関の高さには，6日間といら短期間の調查にお证る 絶対的な変動の少なさも影響を与えているかもし れない，また本研究の結果から，各曜日に打汸る 出来事の評価得点と自尊感情得点との間には有意 な正の相関が見られ, 異なる曜日に抢ける出来事 の評価得点と自尊感情得点との間は無相関であっ た.このことは, Rosenberg（1965）の尺度によっ て测定される自尊感情が，ランダムに生起する測 定誤差によって変動するのではなく，その日に起 きた出来事や経験から影響を受け, 変動しらるこ
とを示している。

そして本研究に抢ける最も重要な知見は，自己 愛傾向の下位側面のうち「注目・賞賛欲求」が, 自己像の不安定性を媒介して日常の自尊感情の変 動性に影響を与えるといら点にある. Rhodewalt et al.（1998）は，自らの研究で自己愛傾向が自尊 感情の変動性に関連した理由として，自己愛的な 者が文脈に依存した，不安定な自己概念をもつた めであると考察している。本研究の結果は，この よらな Rhodewalt et al.（1998）の考察を支持す るものといえるだろら。加えて本研究では自己愛 傾向の下位側面に注目することで，そのような関 連が「注目・賞賛欲求」で見られることを明らか にした。「注目・賞賛欲求」の高い者は，常に他者 からの注目や賞賛を求めており，他者からの賞賛 によって自己を定義づけようとする者であると考 えられる、本研究の結果㳉，この上うな者の自分 自身の捉え方が安定して扮らず，そのためにある 時には自分のことを肯定的に捉え，また別の時に は否定的に捉えるといった，自分自身の評価の一 貫性のなさに結びつくことを示唆している。これ までの研究から，「注目・賞賛欲求」が高い者は友 人からの理解や評価を求め（小塩, 1999), 異性か らの評価を気にする傾向にある（小塩，2000）な ど，他者の自分自身に対する評価に非常に敏感で あることが示されている、本研究の結果から，「注 目・賞賛欲求」の高い者がもつ自分自身の評価の 一貫性のなさが，対人場面に执いては他者からの 評価に対する敏感さといらかたちで表れるのでは ないかと考えられる。

ある程度の自尊感情の高さが心理的な適応を表 すことを考慮すると，日常的な自尊感情レベルの 高さを導く「優越感・有能感」や「自己主張性」 の高い者は，比較的適忍的な状態にあると考えら れる，その一方で「注目・賞賛欲求」の高い者は， 自己像が不安定であるがゆえに日常の自尊感情レ ベルの低下や自尊感情の変動しやすさに結びつく など，必ずしも適応的とはいえない状態にあると 
考えられる.また, 理論的な研究では自己愛の病 理と自己像の不安定性や自尊感情の変動性との関 連が指摘されていることからも，「注目・賞賛欲求」 が比較的病理に近い自己愛を反映することが示唆 される。ただし本研究で見られた「注目・賞賛欲 求」と自己像の不安定性や自尊感情の変動性との 関連は有意ではあるがそれほど大きなものではな かった。「注目・賞賛欲求」が他者からの評価に対 する敏感さに関連するといら先行研究の知見は, 他者からの評価を受けるような場面を経験する場 合に，「注目・賞賛欲求」の高い者の自尊感情がよ り変動することを示唆している。しかし本研究で は日常の出来事の内容には焦点を当てていないた め，本研究の結果のみではどのような出来事を経 験寸る際に自尊感情の変動が見られるのか法か らない。 今後は, 日常の出来事の具体的な内容も 考慮に入れた検討を行っていくことが必要であろ 5 .

\section{引用文献}

Adelson, J., \& Doehrman, M. J. 1980 The psychodynamic approach to adolescence. In J. Adelson (Ed.) Handbook of adolescent psychology. New York: John Wiley \& Sons. Pp.99-116.

American Psychiatric Association 1994 Diagnostic and statistical manual of mental disorders. 4th ed. Washington, D. C. American Psychiatric Association.

Emmons, R. A. 1984 Factor analysis and construct validity of the Narcissistic Personality Inventory. Journal of Personality Assessment, 48, 291300.

Emmons, R. A. 1987 Narcissism: Theory and measurement. Journal of Personality and Social Psychology, 52, 11-17.

遠藤由美 1992 個性化された評価基準からの自尊感 情再考 遠藤辰雄ほか（編） セルフ・エスティー ムの心理学：自己価値の探求 ナカニシヤ出版 Pp.57 -70 .

Gabriel, M. T., Critelli, J. W., \& Ee, J. S. 1994 Narcissistic illusions in self-evaluations of intelligence and attractiveness. Journal of Personali- ty, $\quad 62, \quad 143-155$.

伊藤 洸 1989 コフートの自己愛論 青年心理, 73 , $12-22$.

Jackson, L. A., Ervin, K. S., \& Hodge, C. N. 1992 Narcissism and body image. Journal of Research in Personality, 26, 357-370.

Kernberg, O.F. 1975 Borderline conditions and pathological narcissism. New York: Aronson.

Kernis, M. H., Brown, A. C., \& Brody, G. H. 2000 Fragile self-esteem in children and its associations with perceived patterns of parent-child communication. Journal of Personality, 68, 225252.

Kernis, M. H., Cornell, D. P., Sun, C., Berry, A., \& Harlow, T. 1993 There's more to self-esteem than whether it is high or low: The importance of stability of self-esteem. Journal of Personality and Social Psychology, 65, 1190-1204.

Kernis, M. H., Grannemann, B. D., \& Barclay, L. C. 1992 Stability of self-esteem: Assessment, correlates, and excuse making. Journal of Personality, 60, 621-644.

Kernis, M. H., Whisenhunt, C. R., Waschull, S. B., Greenier, K. D., Berry, A. J., Herlocker, C. E., \& Anderson, C. A. 1998 Multiple faces of self-esteem and their relations to depressive symptoms. Personality and Social Psychology Bulletin, 24, 657-668.

Kohut, H. 1971 The analysis of the self. New York: International Universities Press.

Kugle, C. L., Clements, R. O., \& Powell, P. M. 1983 Level and stability of self-esteem in relation to academic behavior of second graders. Journal of Personality and Social Psychology, 44, 201-207. 小此木啓吾 1981 自己愛人間 朝日出版社

小塩真司 1997 自己愛傾向に関する基礎的研究：自 尊感情, 社会的望ましさとの関連 名古屋大学教育 学部紀要 (心理学)，44，155-163.

小塩真司 1998 青年の自己愛傾向と自尊感情, 友人 関係のあり方との関連 教育心理学研究，46，280290.

小塩真司 1999 高校生における自己愛傾向之友人関 係のあり方との関連 性格心理学研究， 8, 1-11.

小塩真司 2000 青年の自己愛傾向と異性関係：異性 に対する態度, 恋愛関係, 恋愛経験に着目して 名 古屋大学大学院教育発達科学研究科紀要 (心理発達 
科学:), 47, 103-116.

Pulver, S. E. 1970 Narcissism: The term and the concept. Journal of the American Psychiatric Association, 18, 319-341.

Raskin, R., Novacek, J., \& Hogan, R. 1991 Narcissism, self-esteem, and defensive self-enhancement. Journal of Personality, 59, 19-38.

Rhodewalt, F., Madrian, J. C., \& Cheney, S. 1998 Narcissism, self-knowledge organization, and emotional reactivity: The effect of daily experiences on self-esteem and affect. Personality and Social Psychology Bulletin, 24, 75-87.

Rhodewalt, F., \& Morf, C. C. 1995 Self and interpersonal correlates of the narcissistic personality: A review and new findings. Journal of $R e^{-}$ search in Personality, 29, 1-23.

Rosenberg, M. 1965 Society and the adolescent selfimage. Princeton: Princeton University Press. 桜抹茂男 1997 現代に生きる若者たちの心理 風間 莒房

Sedikides, C. 1993 Assessment, enhancement, and verification determinants of the self-evaluation process. Journal of Personality and Social Psy- chology, 65, 317-338.

高比良美刻子 1998 刘人・達成領域別ライフイベン 卜尺度（大学:尘用）の作成之妥当性の検討 社会心 理!学研究, 14, 12-24.

Waschull, S. B., \& Kernis, M. H. 1996 Level and stability of self-esteem as predictors of children's intrinsic motivation and reasons for anger. Personality and Social Psychology Bulletin, 22, 413.

Watson, P. J., \& Biderman, M. D. 1993 Narcissistic personality inventory factors, splitting, and self-consciousness. Journal of Personality Assessment, 61, 41-57.

Westen, D. 1990 The relations among narcissism, egocentrism, self-concept, and self-esteem: Experimental, clinical, and theoretical considerations. Psychoanalysis and Contemporary Thought: A Quarterly of Integrative and Interdisciplinary Studies, 13, 183-239.

Wolf, E., Gedo, J., \& Terman, D. 1972 On the adolescent process as a transformation of the self. Journal of Youth and Adolescence, 1, 257-272. - 2001.3.22. 受稿, 2001.9.21. 受理 -

Atsushi Oshio (Graduate School of Education and Human Development, Nagoya University). Narcissistic personality, instability of self-image, and level of self-esteem and its stability. TH1:

Jaiankise Joliknal, or Pieksonal.tTy 2001, Vol.10 No.1, 35-44.

Some theorists and clinicians have pointed out that self-image and self-esteem of a narcissist were unstable. This study explored the relationship of narcissistic tendency, instability of self-image, and level of self-esteem and its stability. Narcissistic Personality Inventory Short Version (NPI-S) and Stability of Self Scale were administered. Then, daily experiences and their evaluation were recorded for six consecutive days, along with daily self-esteem, by 184 undergraduates (a mean age of 20.3 years). Results indicated that two of the narcissist factors: sense of superiority and competence and assertiveness, positively correlated with level of daily self-esteem. Instability of self-image was a mediator of the effects of the other narcissist factor: need for attention and praise. The instability, which had a positive correlation with the need, correlated negatively with level of daily self-esteem, and positively with instability of daily self-esteem.

Key words: narcissistic personality, self-esteem, stability of self-esteem, instability of self-image 